\title{
FRENCH RESEARCH TRADITIONS ON PEASANT AGRICULTURAL SYSTEMS A convergence with political ecology?
}

\author{
Denis Gautier, Christian A. Kull
}

Author's archived version of book chapter, may contain minor differences with final version. Final version is available through Routledge (book or ebook).

To cite this chapter: Gautier, D \& CA Kull (2015) French research traditions on peasant agricultural systems. In The Routledge Handbook of Political Ecology, edited by Perreault, T, G Bridge \& J McCarthy. London: Routledge, 76-88.

\section{INTRODUCTION}

Political ecology is largely an Anglophone research tradition. It has had, over the years, varying levels of contact and exchange with other linguistic, cultural, and regional research traditions outside its dominant centers in the United Kingdom and United States, via the literature as well as through personal contacts made in the field. Conversely, other national research traditions have been influenced by similar intellectual and contextual forces as those which led to political ecology, but have followed different trajectories. In France, for example, many of the key elements of a political ecological approach are present in the academy - including strong traditions of Marxist anthropology, post-structural inspirations (the names Foucault and Latour are hard to ignore), and field-based studies of agrarian systems - and yet they were never pulled together in the same way as political ecology: instead they produced alternate inspirations and communities of practice.

Knowledge production is geographically embedded, and the particular traditions that have emerged in France carry the imprint of that nation's own social, institutional, (post)colonial, and disciplinary history. Of relevance to typical political ecological themes, one might mention three strong Francophone traditions. First, tropical geography, with its focus on the terroir as the portion of land appropriated, managed, and used by the group that resides upon it (Sautter and Pélissier 1964; Blanc-Pamard and Cambrézy 1995; Bowd and Clayton 2005; Bassett et al. 2007; Gautier and Hautdidier forthcoming). Second, hydrogeographies, or integrated watershed studies, where critical considerations of political discourse, institutional structures, and power relations have been layered upon strong technical hydrological traditions (Molle 2008; Bouleau et al. 2009; Venot and Krishnan 2011; Blanchon and Graefe 2012; Bouleau 2014). Third, agrarian systems research - the focus of this chapter - which has always gone beyond straight agronomy to understanding farmers in a broader societal, political, economic, and developmental context.

In this chapter, we focus on the latter tradition of research on peasant agricultural systems, for its parallels and divergences with political ecology are instructive. We document its origins and character, and place it in socio-political context - for the kind of research that has 
emerged in this tradition is reflected in the mandates of its main institutional hosts, which themselves are shaped by France's own agrarian politics (at home) and postcolonial development legacy (overseas). We dissect the core assertions and concepts of the approach, and focus in particular on its approach to questions of land tenure and resource access - an area with obvious overlaps to political ecology. Then we conclude with a consideration of potential synergies despite the relatively limited exchange to date between the approaches.

\section{SYSTÈMES AGRAIRES: ORIGINS}

"Systèmes agraires", or agrarian systems, is a set of approaches across French research institutions that studies rural farming communities at multiple scales and from both agrotechnical and socio-economic perspectives. It encompasses detailed technical work on crop choices, rotations, tools, and practices; mid-scale analyses of the production system at the farm level (including land, labor, and capital); and - importantly - the higher order systems that emerge from relationships between farm systems and the overall economic, social, and bio-ecological worlds in which they are embedded. Systèmes agraires can and does take seriously the relations of production, questions of resource access, and the broad political, social, and economic contexts within which people seek to exploit and manage the environment, even if it is mainly with a technical and not actor-centered perspective.

The systèmes agraires approach emerged in the 1970s and has a history that parallels - with overlaps and disjunctures - the evolution of kindred approaches in the Anglophone world in the same time period. The most obvious overlap is with "farming systems research" (Norman 1980), which in the Anglophone world had an institutional base in natural resource management schools and agricultural faculties. While the two approaches appear similar on the surface, the overlap is largely constrained to the middle of the three scales of analysis common to systèmes agraires research, as we detail later. Indeed, farming systems research is illustrative of the "apolitical" approaches in response to which political ecology emerged. A second parallel would be with anthropologists and geographers working in "cultural ecology" and "human ecology", often in rural tropical landscapes, and who shared an interest in particular techniques and the local cultural systems in which they were embedded. At the boundaries between cultural ecology and farming systems research, scholars sought to compare rural farm societies (e.g. Turner and Brush 1987) in ways that approached what was happening in the French tradition, but with less emphasis on the broad political economic context. Finally, scholars from "agrarian studies" and "peasant studies" traditions approached rural societies with primary attention on labor and power dynamics and built a critique of rural marginalization.

The term systèmes agraires was first used in the 1940s by rural geographer Cholley (1946) in a way that emphasized the dynamic, evolving nature of agrarian societies and their systemic interactions. However, his dynamic vision of the concept was more often replaced by a more static concern with agrarian structures (structures agraires) - a more descriptive combination of analysis of spatial farm organization and tenure regimes (Cochet 2012).

With the growing popularity of "systems theory" in the 1960s and 1970s, the time was ripe for systèmes agraires to develop. There was a flourishing of francophone writings based on a systemic perspectives (Piaget 1968; de Rosnay 1975; Crozier and Friedberg 1977; Le Moigne 1977; Morin 1977) inspired by, among others, the work of von Bertallanfy $(1936,1968)$ and also by the first 'classic' works published at this time in the United States such as 'Systems Approach' (Churchman 1979), 'Systems Analysis' (Hare 1967), 'System Theory' (Zadeh 
1962), or 'System Dynamics' (Forrester 1971). Popular French public intellectual Joël de Rosnay (1975), for instance, studied systems at MIT. In the realm of agrarian studies, Osty was one of first the researchers to promote the application of a systemic perspective. He wrote: "it is considering first the whole before studying deeply all the parts that we know how to analyze and that the farm is an organized whole that does not reply to simple criteria of optimization" (Osty 1978). His work on 'the farm viewed as a system' contributed to a new vision of agronomical studies that sought to better understand farmers' practices and choices, and thus to adapt extension efforts. His approach was influenced by Crozier and Friedberg (1977), for whom the actor does not exist outside the system that defines his liberty and the rationality that he can use for his actions, and conversely, for whom the system exists only as a construction of the actions and interests of different actors.

\section{INSTITUTIONAL CONTEXTS}

The story of how systèmes agraires developed in French research circles is tightly linked to the institutional context. A number of different, but related, approaches developed in the major French research institutions. Whereas much similar work in the Anglophone context takes place by individual researchers scattered across numerous universities, in the French context there is a large role played by government and parastatal research agencies. These agencies provide placements for PhD students being trained, and have established networks and facilities for field-based studies in France and overseas. In addition, the relatively centralized and hierarchical way in which academia functions in France gives quite some weight to dominant research programs. In this section we trace the context of the production of knowledge related to systèmes agraires across four main institutions.

\section{ORSTOM (now IRD)}

The French government created an organization dedicated to research in its colonies in 1943. It was called ORSTOM (Office de la recherche scientifique et technique outre-mer) reflecting its focus on overseas scientific and technical research. ORSTOM developed a tradition of interdisciplinary studies of village territories or small regions in developing countries. Paul Pélissier and Gilles Sautter (Sautter and Pélissier 1964; Pélissier 1966; Pélissier and Sautter 1970), as well as Augé (1970), Lericollais (1972), Boulet (1975) and others, published remarkable examples of a holistic and systemic approaches of agrarian societies. However, their studies were generally focused on the concept of 'terroir', which refers to a portion of land appropriated, managed and used by the group that resides upon it and draws from it their means of existence (Sautter and Pélissier 1964). The 'terroir school' contributed to knowledge of peasant agriculture, nature-society relations in rural areas, and the efficiency of production systems, but at a village territory level (Pélissier 1979; Bassett et al. 2007).

ORSTOM's role in the genesis of French agrarian studies came via the activities of AMIRA ("l'Amélioration des Méthodes d'Investigation en milieu Rural Africain" [Improvement of Methods of Investigation in the African Rural Areas]). This was an informal group specializing in methodological research, active from 1975 to 1990, that linked ORSTOM, the French Ministry of Cooperation, and the national statistics agency INSEE (Institut national de la statistique et des études économiques). Building on the 'terroir' studies described above, AMIRA aimed to contribute to renewing the methodological tools for investigating and analyzing the development process, as well as the importance of data, its gathering, processing, analysis and use. Accordingly AMIRA had a prominent role in the genesis of French agrarian systems studies (Ancey 1975). 
From the late 1970s, ORSTOM began to expand beyond its detailed 'terroir' scale studies through two research units: "Cadres spatiaux de l'indépendance alimentaire" [Spatial frameworks of food independence] and "Dynamique des Systèmes de production" [Dynamic of production systems]. This latter group was focused on the circumstances and causes of the changes in rural societies at different scales: the plot, the farm, and the small region, bringing together multidisciplinary teams of agronomists, economists, geographers and sociologists (Ancey 1977; Couty and Hallaire 1980; Hallaire and Savonnet 1985; Dubois et al. 1987). This research contributed to exploding outward the restricted framework of the 'terroir' to promote the study of agrarian systems.

With decolonization the mission of ORSTOM mutated into more of a development cooperation role, symbolized (belatedly) by its name change in 1998 to IRD, or Institut de recherche pour le développement (Research institute for development). It is jointly overseen by the Ministry of Higher Education and Research and the Ministry of Foreign Affairs (which includes development cooperation). It has active missions and country offices in most French overseas territories, across the ex-French colonial world, and in other developing countries like Indonesia, Kenya, Brazil, and Peru. Some of its current research groups, notably GRED (Gouvernance, Risque, Environnement, Développement), have been keen to build bridges with political ecology.

\section{L'Institut national agronomique Paris-Grignon (INA P-G)}

The 'Agro' is a venerable institution, an elite, competitive-entry university with a mission of training civil servants in agricultural fields. It recently merged with the water and forestryfocused ENGREF to form AgroParisTech, one of France's so-called 'grandes écoles'. It is here that a Chair of Comparative agriculture and agricultural development was established and held by René Dumont from 1953 to 1973, followed by Marcel Mazoyer from 1974 to the early 2000s. From this position, the "French school of comparative agriculture" has been strongly promoted and has had a strong role in developing the concept of système agraire (Cochet 2012). This school of thought investigates the specificities of, and similarities between, the diverse forms of contemporary agriculture worldwide. It emphasizes the historical agricultural development of given societies and analyses the linkages between the remnants of former agrarian systems and the elements of new ones. It seeks to draw overarching lessons to understand agricultural development, including those interpreted as 'crises' or 'revolutions', but avoiding broad generalizations or overly simplified modeling (Mazoyer and Roudart 1998; Dufumier 2006).

\section{INRA}

The Institut national de la recherche agronomique is a large research organization focused on agriculture, largely in France, and is jointly overseen by the Agriculture and Research ministries. During the post-war period - the so-called Trente glorieuses (or three decades of socio-economic prosperity) - French agriculture rapidly transformed and intensified, and INRA played an important role developing crop varieties and cultivation techniques, largely through a technical and micro-economic approach. In the later 1960s and 1970s, however, these sectoral technical approaches were integrated with a more global approach. A think tank on non-sectoral research was established, under the leadership of R. Gras. Simultaneously, J.P. Deffontaines of the INRA's Service d'Expérimentation et d'Information (SEI, for [Experimental and informational program]), just after having defended a Ph.D. in geography, developed an approach that set the farms and their dynamic in their geographical context in mountainous regions (Deffontaines 1977). It is worth noticing that in its initial phases, this kind of research often focused on marginal regions where the application of INRA's mainstream models of development and innovations transfer were causing serious problems. 
This kind of work by the SEI led to the establishment of a long-lasting department of Systèmes agraires et développement (SAD) within INRA in 1979 (Deffontaines 1980). Created to study the resistance of farmers to the adoption of innovation, the SAD from the beginning has brought together researchers from both the agronomic and social sciences, and centered its studies on practices, organizations, and perceptions linked to farming and natural resource management (Meynard 2010). It has been one of the pioneers of interdisciplinary research on the rural world (Deffontaines and Hubert 2004).

\section{CIRAD}

A fourth venue for systèmes agraires research is CIRAD (Centre de coopération internationale en recherche agronomique pour le développement, or the center for international cooperation in agricultural research for development). This major institution, with a presence across the tropical developing world, was created in 1984 out of the amalgamation of a number technical institutes mainly dedicated to the cash crops of the former French colonial Empire. It is jointly answerable to the Ministries of Agriculture, Foreign Affairs and Higher Education and Research. Generally focused on the industrial production of crops, such as palm oil, cotton, coffee, cocoa, and rubber, among others, these technical institutes tested crop improvements and techniques in laboratories or in experimental plots before seeking to transfer them to industrial groups, large modern farms, or peasants. However, it was realized that this transfer was more difficult in the case of food crops and small family farms. It was the technical institute in charge of the food crops, IRAT (Institut de recherches agronomiques et des cultures vivrières [Agricultural research institute for subsistence crops]) that first realized the necessity of escaping from the experimental domain to meet local people and understand their realities, in order to ensure better innovation transfer. The remarkable work of R. Tourte and his team in Sine Saloum, Senegal, which began in 1963, served as a foundation of agrarian studies within CIRAD (Kleene 1976; Tourte and Billaz 1982). This innovative approach led to the creation of an Agrarian Systems unit within IRAT in 1982, and then to the creation of CIRAD's Department of Agrarian Systems (DSA) in 1984.

\section{Convergence}

Despite the different backgrounds and institutional contexts, a systemic approach to agrarian studies spread quickly from the late 1970 across all these institutions, converging to become a distinct, consistent and uniform approach (Brossier et al. 1990; Brossier et al. 1993; de Bonneval 1993) that sought to understand and integrate the complexity of rural activities (Conesa 1987). The uptake of this approach was motivated by an acknowledgment that technological advances in agronomy could not be implemented, or would not be adopted, without an understanding of farmers' behaviors and their broader socio-economic context. Often, the approach passed in France under the rather generic label 'RechercheDéveloppement' (Pillot 1987). The pioneering groups founded in the 1970s and 1980s no longer exist under the same names except at INRA. But the theoretical basis of agrarian system studies continues to influence these research communities, even if they have been overtaken by more recent academic concerns such as local or territorial development (Caron 2005; Benoît et al. 2006). Research training in agrarian system studies remains particularly strong in the agronomic universities such as AgroParisTech (formerly INA-Paris Grignon) and SupAgro Montpellier as well as in some academic geography programs.

\section{AGRARIAN SYSTEMS AT THREE SCALES}


The systèmes agraires approach spans a number of different scales. Compared to political ecology and its residual influence from cultural ecology, there is a much stronger focus on agronomic practices at the smaller scale, and an orientation towards not just analyzing but also promoting change and adaptation. Here we present an overview of the three main scales of analysis, keeping in mind that the concepts have evolved over the decades.

The overall aim of systèmes agraires is to understand the agrarian system by studying its structure and character at different scales and the interactions between these scales. As the lowest level of scale, the study of cropping and livestock technical systems investigates in specific detail how farmers exploit and manage their environment, describing the particular patterns of activities for each type of crop or land use. It focuses on vegetal dynamics in cropfields and pastures, the 'technical itineraries' (or combinations of tools, techniques, and practices that allow farmers to shape the environment for productive use - (Sébillotte 1974)), and the plots or territories in which this occurs (Sebillotte 1982; Landais 1983; Lhoste 1984). The cropping and livestock technical systems are components of the farming system, but may be analyzed at a scale that is larger than the farm when they are related to practices of cropping or herding that are common to several farms.

The système de production, or production system, takes the analysis up one level of scale. It also moves away from strictly technical and agro-ecological analysis to consider the socioeconomic system at the whole-farm scale. A production system has been defined as a combination, more or less coherent in space and time, of diverse means of production (labor, land, buildings, input, material, tools, livestock, etc.) in order to satisfy the farmer's socioeconomic and cultural objectives at the farm level (Chombart de Lauwe et al. 1963; Tourte 1978; IRAM 1985). It should be noted that some authors use the term système de production somewhat differently, as a label for dominant aggregations of micro-economic at the regional level, such as the "cotton-sorghum system in the sudano-sahelian area". Such production systems are then used as a statistical unit for macro-economic analysis (Reboul 1976). However, in its most common sense at the micro-economic level, the definition of the French système de production and the Anglophone "farming system" are similar (Norman 1980; Pillot 1987). They both open the door to political economic analyses of farm labor, land tenure, and resource access. Thus, they both provide components for political ecology analyses. Yet conceptual differences appear when either scaling down or especially when scaling-up.

The highest scale, the French notion of système agraire, acknowledges that interacting production systems are constitutive elements of a higher-order system, which emerges from the relationship between production systems and the overall economic and social structure. This is the original agrarian system idea - looking at an agrarian society and the lands that it uses through the twinned interactions of the bio-ecological system and the socio-cultural system (Deffontaines and Osty 1977; Vissac 1979). The idea was to go beyond the simple understanding of the internal functioning of the "production system" to take in consideration the overall conditions of production.

Marcel Mazoyer, of the comparative agriculture school at INA-PG, presented an important critique of this original conception of agrarian systems as interactions of the bio-ecologic and the socio-cultural. He argued that it was too static, and proposed a less structuralist, more dynamic definition: "An agrarian system is a way of exploitation of the environment, evolved through time and lasting, a system with growth of production, adapted to bio-climatic conditions of a given area and answering the current conditions and needs. The internal 
coherence of the way of exploitation of the environment raises questions about the overall technical, economic and social conditions of production" (Mazoyer 1987: 11). For Mazoyer, an agrarian system is a combination of the following essential variables in one form or another:

- the cultivated ecosystem: the original environment and its historical transformations to its present state

- the production elements: tools, machines, plant cultivars, domesticated animals, and the social labor force (physical and intellectual) to manage them.

- the social division of labor between agriculture, craft industry and industry which allow the reproduction of work tools, and then the agricultural surplus that allows the satisfaction of other social groups, beyond the needs of the farmers.

- the exchange relationships between these different but associated sectors, the relations of ownership and power which determine the share of the production work, of the production and consumer goods.

- finally, the overall ideas and institutions, which allow social reproduction: production and exchange relationships and the sharing of production.

Agronomist Philippe Jouve (1988) added a more explicit consideration of space to the concept, and made the spatial and territorial aspects even more explicit in his development of a 'rural systems' concept to replace 'agrarian systems' (Jouve 1992). The framework of the 'rural system' allows one to consider the increasing importance of off-farm activities and migration, while also enabling integration of all functioning elements of a rural society, such as health and religion.

\section{THE SYSTÈMES AGRAIRES APPROACH IN COMPARISON WITH POLITICAL ECOLOGY, THEN AND NOW}

Compared with contemporaneous Anglophone research traditions, if one may generalize, the systèmes agraires approach had no direct equivalent. It was more applied and geared towards effecting change - modernizing - than 'cultural ecology' and 'human ecology' approaches interested in how indigenous societies differed from modern ones. It brought much more technical and agro-ecological focus to the table than the traditions of 'peasant studies' and 'agrarian studies', while sharing the sharp focus on relations and modes of production. While it overlapped considerably with 'farming systems' approaches in its intermediate analytical scale of systèmes de production, the systèmes agraires approach differed in giving a full account of the historical social and economic transformations at multiple scales that impact the processes of agricultural production. It also differed in better accommodating nonagricultural activities into its framework (Behnke and Kerven 1983; Tripp 1985). In a way, the Francophone agrarian systems approach was considering the historical transformations and political economic processes that political ecology sought to do in its own critique of 'farming systems' approaches.

However, the challenge for systèmes agraires approaches has been to deal with current rapid transformations: globalizing trade, restructuring economies, and evolving world institutions. Few systèmes agraires scholars have paid much attention to the fact that agricultural modernization, for instance, has been leading to a marginalization and disappearance of small-scale farmers - the petit paysannat. As Cochet (2012: 133) notes, "it is easier to analyze a relatively 'stable' situation and construct an agrarian system ... than to analyze a system that is so dynamic that the various elements and their reciprocating interactions just barely have the time to stabilize before transforming again..... Perhaps the agrarian system concept is easier to wield when applied to history, to lay the groundwork of a system, than to 
rapidly changing modern agriculture." These observations notwithstanding, both Dufumier (2007) and Cochet (2012) and defend the systèmes agraires approach as profoundly relevant to analyzing such crises in agrarian systems and the processes that lead to their restructuring in different forms.

Undoubtedly, in its overall emphases, systèmes agraires focuses more attention on technical and agro-ecological aspects than political ecology. In turn, political ecology stresses not just production relations and global political economy (in concert with systèmes agraires), but also more particular attention to the institutional and discursive ways in which power relations play out. One area in which there has been significant overlap, if not interaction, is in the study of access rights and resource tenure. Researchers linked to ORSTOM/IRD and CIRAD have a long tradition of paying attention to the rights of access to land and resource and the conflicts around land tenure and use (Le Bris et al. 1982; Blanc-Pamard and Cambrézy 1995; Le Roy et al. 1996) and to theorizing the relationship of societies to land (Le Roy 1996). Even if political ecological research makes few explicit links via citation, it is likely that French research efforts on land tenure and access, particularly those focused on Africa, has had some influence on Anglophone political ecology (Bassett 1988; Kull 1998; Ribot 1999).

Conversely, some francophone work on land tenure issues and their relation to territorial policies presents strong similarities with research in political ecology, and has, since the year 2000, started to explicitly cite it (Chauveau 1997; Chauveau 2000; Chauveau and Jacob 2006; Jacob 2007; Jacob and Le Meur 2010; Medernach and Burnod 2013).

These exceptions notwithstanding, until recent exchanges (see below), there have been few strong theoretical links made between political ecology and the French agrarian system approach. This is surprising given the strong similarities between, for instance, studies of land tenure and land use in the francophone tradition of agrarian system research and the Anglophone corpus of political ecology (Bertrand et al. 2004). It appears to be more of a case of parallel or convergent evolution than a strong, direct connection. Beyond tenure issues, there are numerous divergences: for instance, the systèmes agraires approach does not pay much attention to the winners and the losers of rural development or environmental policies at the local level, nor do systèmes agraires studies frequently incorporate gender concerns.

It is only since the 2000 s that a generation of French scholars who received a preliminary training in the systèmes agraires approach has been clearly inspired by some political ecology. This comes from personal interactions with Anglophone political ecologists through work in the field or academic exchanges, attending AAG conferences, or simply by the percolation of ideas from colleagues who have themselves been inspired by the political and social commitment which is often missing in the agrarian system studies. One of the earliest French publications to recognize political ecology was an article by Blanc-Pamard and Boutrais (2003). This article cites political ecologists Piers Blaikie, Melissa Leach, and Raymond Bryant in a review of 50 years of development policy in the environment sector. Tom Bassett, who has long-standing relations with the Centre d'Etudes Africaines (home to the authors of that article), introduced geographers there to this approach in the 1990s.

The more forceful entry of political ecology on the French scene took place in the late 2000s, when the approach was embraced by a new generation of young researchers mainly trained in agrarian systems. Their enthusiasm for political ecology was championed and given institutional weight by established researchers like Bernard Hubert, President of Agropolis, a major multi-institutional hub of agricultural and development research in Montpellier, and Serge Bahuchet, director of the research group in eco-anthropology and ethnobiology at the 
Paris Natural History Museum (MNHN). In 2009, for example, CIRAD invited a number of prominent political ecological scholars (Paul Robbins, Tom Bassett, Nancy Peluso, Tor Benjaminsen) for a research school ${ }^{1}$, program evaluation workshops, and public lectures in the framework of the SETER project (Socio-Ecological Theories and Empirical Research) ${ }^{2}$. The first articles in French on political ecology appeared in Natures, Sciences, Sociétés in 2009 (Benjaminsen and Svarstad 2009; Castro-Larrañaga 2009), and the first book - a result of the 2009 research school - in 2012 (Gautier and Benjaminsen 2012). A number of small informal research groups are now coalescing along political ecological themes in diverse institutions ranging from CIRAD, IRD, MNHN, to the National Institute for Research in Sciences and Technologies for Environment and Agriculture (IRSTEA).

Why this explosion of interest in Anglo-American political ecology? Two main reasons appear important. First, the dominance of the English language in an internationalizing academia has certainly helped. Young French researchers are encouraged to do post-docs in Anglophone countries, attend overseas conferences, and to publish in international, thus English-language, journals. This has increased exposure to Anglophone traditions, creating both inspiration as well as the need to 'fit in'. Second, we suggest that political ecology has grown because it helps researchers legitimate a more critical stance than hitherto possible under agrarian systems approaches (which were, after all, relatively technical and applied) and under their host institutions (which are part of the state's machinery and in some cases, carry postcolonial legacies, albeit fading ones). Researchers seeking a more engaged approach that allows for the construction of tighter links between politics (broadly construed) and the environment can call on political ecology as a solid justificatory framework to do so.

\section{CONCLUSION}

With its opening towards political ecology in the past few years, French research has gained a legitimation for more critical approaches to work on agrarian change (Eloy 2005; Ducourtieux 2006), hydro-management (Bouleau 2014), and natural resource management (Gautier et al. 2011; Gautier et al. 2013). There are some signs of convergence between the 'systèmes agraires' tradition and Anglophone political ecology that allows a more critical approach within the French institutional context. Even if this convergence is still limited to individuals spread in different institutions, and even if political ecology is not taught as such in an academic program, an informal community is emerging that is building strong links between the agrarian systems and the political ecology traditions.

Yet the exchanges are largely unidirectional. It is relatively rare to find references to French agrarian systems literature, or its more modern manifestations, in Anglophone political ecology texts, except where researchers share field sites. There is surely much to be gained for political ecology from not just the very detailed systemic studies of the agricultural or livestock technical systems found in the French systèmes agraires tradition, but also from its structured, systemic approach to understanding the complex character of regional agrarian systems in all their bio-ecological and social splendor. For those seeking inspiration, some exemplary studies (such as Couty 1991; Aubert et al. 2003; Blanc-Pamard et al. 2005; Barnaud 2008) show how a systèmes agraires approach can provide strong field evidence to demonstrate the effects of development policies on rural societies and their environment.

\footnotetext{
${ }^{1}$ www.politicalecology.fr

${ }^{2}$ http://www.seter.org/index.php/
} 


\section{REFERENCES}

Ancey, G. (1975) Niveaux de décision et fonctions objectif en milieu rural africain. AMIRA, note de travail $n^{\circ} 3$. Paris: ORSTOM.

Ancey, G. (1977) "Recensement et description des principaux systèmes ruraux sahéliens." Cah. ORSTOM Sc. Hum., Vol. 14, pp. 3-19.

Aubert, S., S. Razafiarison and A. Bertrand (2003). Déforestation et systèmes agraires à Madagascar: les dynamiques des tavy sur la côte orientale. Versailles: Editions Quae.

Augé, M. (1970) "Tradition et conservatisme Essai de lecture d'un terroir: Pays Alladian (Basse Côted'Ivoire)." Etudes rurales, Vol. 37-39, pp. 281-298.

Barnaud, C. (2008) Equité, jeux de pouvoir et légitimité: les dilemmes d'une gestion concertée des ressources renouvelables. Mise à l'épreuve d'une posture d'accompagnement critique dans deux systèmes agraires des hautes terres du Nord de la Thaïlande. PhD thesis, Université de Nanterre-Paris $\mathrm{X}$.

Bassett, T.J. (1988) "The Political Ecology of Peasant-Herder Conflicts in the Northern Ivory Coast." Annals of the Association of American Geographers, Vol. 78, pp. 453 - 472.

Bassett, T.J., C. Blanc-Pamard and J. Boutrais. (2007) "Constructing Locality: The Terroir Approach in West Africa." Africa, Vol. 77, pp. 104-129.

Behnke, R. and C. Kerven. (1983) "FSR and the attempt to understand the goals and motivations of farmers." Culture and Agriculture, Vol. 19, pp. 9-16.

Benjaminsen, T.A. and H. Svarstad. (2009) "Qu'est-ce que la "political ecology»?" Natures Sciences Sociétés, Vol. 17, pp. 3-11.

Benoît, M., J.-P. Deffontaines and S. Lardon (2006). Acteurs et territoires locaux : vers une géoagronomie de l'aménagement. Versailles: Editions Quae.

Bertrand, A., J.C. Ribot and P. Montagne. (2004) "The historical origins of deforestation and forestry policy in French-speaking Africa: from superstition to reality?". In Babin, D. (eds.), Beyond tropical deforestation: from tropical deforestation to forest cover dynamics and forest development, Paris: UNESCO, pp. 451-463.

Blanc-pamard, C. and J. Boutrais. (2003) "Les temps de l'environnement. D'un sauvetage technique à une gestion locale en Afrique et à Madagascar." Historiens et Géographes, Regards sur l'Afrique, Vol., pp. 249-262.

Blanc-Pamard, C. and L. Cambrézy. (eds.) (1995) Dynamique des systèmes agraires : terre, terroir, territoire : les tensions foncières. Collection Colloques et Séminaires. Paris: ORSTOM.

Blanc-Pamard, C., P. Milleville, M. Grouzis, F. Lasry and S. Razanaka. (2005) "Une alliance de disciplines sur une question environnementale : la déforestation en forêt des Mikea (Sud-Ouest de Madagascar)." Natures Sciences Sociétés, Vol. 13, pp. 7-20.

Blanchon, D. and O. Graefe. (2012) "La radical political ecology de l'eau à Khartoum. Une approche théorique au-delà de l'étude de cas." L'Espace géographique, Vol., pp. 35-50.

Bouleau, G. (2014) "The co-production of science and waterscapes: The case of the Seine and the Rhône Rivers, France." Geoforum, Vol. Forthcoming, pp.

Bouleau, G., C. Argillier, Y. Souchon, C. Barthélémy and M. Babut. (2009) "How ecological indicators construction reveals social changes-The case of lakes and rivers in France." Ecological indicators, Vol. 9, pp. 1198-1205.

Boulet, J. (1975) Magoumaz, pays Mafa (Nord Cameroun): Étude d'un Terroir de Montagne. Paris: ORSTOM.

Bowd, G. and D. Clayton. (2005) "French tropical geographies: editors' introduction." Singapore Journal of Tropical Geography, Vol. 26, pp. 271-288.

Brossier, J., L. de Bonneval and E. Landais (1993). Systems studies in agriculture and rural development Institut National de la Recherche Agronomique (INRA).

Brossier, J., B. Vissac and J.-L. Le Moigne. (1990) "Modélisation systémique et système agraire: décision et organisation". Actes du séminaire du Département de recherches sur les systèmes 
agraires et le développement (SAD), Saint-Maximin, France: Institut national de la recherche agronomique

Caron, P. (2005) "À quels territoires s' intéressent les agronomes? Le point de vue d'un géographe tropicaliste." Natures Sciences Sociétés, Vol. 13, pp. 145-153.

Castro-Larrañaga, M.V. (2009) "Commentaire du texte de Benjaminsen et Svarstad : "Qu'est-ce que la political ecology"?" Natures Sciences Sociétés, Vol. 17, pp. 12-17.

Chauveau, J.-P. (1997) "Jeu foncier, institutions d'accès à la ressource et usage de la ressource". In Contamin, B. and H. Memel-Fotê (eds.), Le modèle ivoirien en questions: crises, ajustements, recompositions, Paris: Karthala, pp. 325-360.

Chauveau, J.-P. (2000) "Question foncière et construction nationale en Côte d'Ivoire." Politique africaine, Vol., pp. 94-125.

Chauveau, J.-P. and J.-P. Jacob (2006). Modes d'accès à la terre, marchés fonciers, gouvernance et politiques foncières en Afrique de l'Ouest. London: IIED.

Cholley, A. (1946) "Problèmes de structure agraire et d'économie rurale." Annales de géographie, Vol. LV, pp. 81-101.

Chombart de Lauwe, J., J. Poitevin and J.-C. Tirel (1963). Nouvelle gestion des exploitations agricoles. Deuxième Edition. Paris: Dunod.

Churchman, C.W. (1979). The systems approach and its enemiesBasic Books New York.

Cochet, H. (2012) "The "systeme agraire" concept in francophone peasant studies." Geoforum, Vol.

43, pp. 128-136.

Conesa, A.P. (1987) "Equipes francaises systemes agraires." Cahiers de la recherche developpement, Vol., pp. 1-2.

Couty, P. (1991) "L'agriculture africaine en réserve. Réflexions sur l'innovation et l'intensification agricoles en Afrique tropicale." Cahiers d'études africaines, Vol. 31, pp. 65-81.

Couty, P. and A. Hallaire (1980) De la carte aux systèmes. Vingt ans d'études agraires au Sud du

Sahara. (ORSTOM, 1960 - 1980). Note AMIRA n²9. Paris: ORSTOM. pp. 121.

Crozier, M. and E. Friedberg (1977). L'acteur et le système. Paris: Éditions du Seuil.

de Bonneval, L. (1993). Systèmes Agraires. Systèmes de Production. Vocabulaire français-anglais avec index anglais [Agricultural systems. Production systems. French-English Dictionary with English index]. Paris: INRA.

de Rosnay, J. (1975). Le Macroscope : vers une vision globale. Paris: Éditions du Seuil.

Deffontaines, J.-P. (1977) "Aménagement et espace: Evolution des exploitations agricoles et transformation de l'espace." Économie rurale, Vol. 119, pp. 28-28.

Deffontaines, J.-P. (1980) "Systèmes de pratiques et terroirs. Pour une approche agronomique des systèmes agraires". Carribean Seminar on Farming Systems Research Methodology, IICA, INRA, Pointe à Pitre, pp. 163-177.

Deffontaines, J.-P. and B. Hubert. (2004) "Un regard sur l'interdisciplinarité à l'Inra." Natures Sciences Sociétés, Vol. 12, pp. 186-190.

Deffontaines, J.-P. and P.-L. Osty. (1977) "Des systèmes de production agricole aux systèmes agraires." Espace géographique, Vol. 6, pp. 195-199.

Dubois, J.-P., A. Lericollais, P. Milleville and G. Pontié. (1987) "Terroirs anciens, approche renouvelée : analyse du changement dans les systèmes agraires au Sénégal". Communication au séminaire Dynamique des Systèmes Agraires, Paris, pp. 38.

Ducourtieux, O. (2006) Du riz et des arbres: L'élimination de l'agriculture d'abattis-brûlis, une constante politique au Laos. Thèse de doctorat en agriculture comparée, INA P-G (AgroParisTech). Dufumier, M. (2006) "Diversité des exploitations agricoles et pluriactivité des agriculteurs dans le Tiers Monde." Cahiers Agricultures, Vol. 15, pp. 584-588.

Dufumier, M. (2007) "Agriculture comparée et développement agricole." Revue Tiers Monde, Vol., pp. 611-626.

Eloy, L. (2005) Entre ville et forêt : le futur de l'agriculture amérindienne en question. Thèse de Doctorat en géographie, Université de Paris III/ IHEAL.

Forrester, J.W. (1971). World dynamics. Cambridge, Mass.: Wright-Allen. 
Gautier, D. and T.A. Benjaminsen. (eds.) (2012) Environnement, discours et pouvoir: L'approche Political ecology. Versailles, France: Editions Quae.

Gautier, D., T.A. Benjaminsen, L. Gazull and M. Antona. (2013) "Neoliberal Forest Reform in Mali: Adverse Effects of a World Bank "Success"." Society \& Natural Resources, Vol. 26, pp. 702-716.

Gautier, D. and B. Hautdidier. (forthcoming) "Connecting political ecology and French geography: on tropicality and radical thought". In Bryant, R.L. (eds.), International Handbook of Political Ecology, Cheltenham: Edward Elgar.

Gautier, D., B. Hautdidier and L. Gazull. (2011) "Woodcutting and territorial claims in Mali." Geoforum, Vol. 42, pp. 28-39.

Hallaire, A. and G. Savonnet. (1985) "Le terroir, une formule rigide, ses transformations, ses éclatements". In Blanc-Pamard, C. and A. Lericollais (eds.), A travers Champs, agronomes et géographes. Dynamique des systèmes agraires, Paris: ORSTOM, Colloques et séminaires, pp. 31-56. Hare, V.C. (1967). Systems analysis: a diagnostic approach. Nwe York: Harcourt, Brace and World. IRAM (1985) Recherche-Développement, compte-rendu des journées d'étude 12-13 septembre 1984. Paris.

Jacob, J.-P. (2007). Terres privées, terres communes. Gouvernement de la nature et des hommes en pays winye, Burkina Faso. Paris: IRD éditions.

Jacob, J.-P. and P.-Y. Le Meur. (2010) "Citoyenneté locale, foncier, appartenance et reconnaissance dans les sociétés du Sud". In Jacob, J.-P. and P.-Y. Le Meur (eds.), Politique de la terre et de l'appartenance. Droits fonciers et citoyenneté locale dans les sociétés du Sud, Paris: Karthala, pp. 557. Jouve, P. (1988) "Quelques réflexions sur la spécificité et l'identification des systèmes agraires." Les cahiers de la recherche développement, Vol. 20, pp. 5-16.

Jouve, P. (1992). Le Diagnostic du milieu rural de la region a la parcelle: approche systémique des modes d'exploitation agricole du milieu. Montpellier, France: CNEARC.

Kleene, P. (1976) "Notion d'exploitation agricole et modernisation en milieu Wolof Saloum (Sénégal)." L'Agronomie tropicale, Vol. 31, pp. 63-81.

Kull, C.A. (1998) "Leimavo Revisited: Agrarian Land-Use Change in the Highlands of Madagascar." The Professional Geographer, Vol. 50, pp. 163-176.

Landais, E. (1983). Analyse des systèmes d'élevage bovin sédentaire du Nord de la Côte d'Ivoire. Maisons-Alfort, France: IEMVT.

Le Bris, E., E. Le Roy and F. Leimdorfer. (eds.) (1982) Enjeux fonciers en Afrique Noire. Paris: ORSTOM - Karthala.

Le Moigne, J.-L. (1977). La théorie du système général. Théorie de la modélisation. Paris: PUF. Le Roy, E. (1996) "La théorie des maîtrises foncières". In Le Roy, E., A. Karsenty and A. Bertrand (eds.), La sécurisation foncière en Afrique, pour une gestion viable des ressources renouvelables, Paris: Karthala, pp. 59-76.

Le Roy, E., A. Karsenty and A. Bertrand. (eds.) (1996) La sécurisation foncière en Afrique. Pour une gestion viable des ressources renouvelables. Paris: Karthala.

Lericollais, A. (1972). Sob: étude géographique d'un terroir sérèr (Sénégal)IRD Editions.

Lhoste, P. (1984) "Le diagnostic sur le système d'élevage." Les cahiers de la recherche et de développement, Vol., pp. 84-88.

Mazoyer, M. (1987) Dynamique des Systèmes agraires. Rapport de synthèse présenté au Comité des systèmes agraires. Paris, France: Ministère de la Recherche et de la technologie.

Mazoyer, M. and L. Roudart (1998). Histoire des agricultures du monde : Du néolithique à la crise contemporaine. Paris: Seuil.

Medernach, K. and P. Burnod. (2013) "Recompositions inattendues d'un système agraire malgache par l'agrobusiness." Etudes rurales, Vol. 1, pp. 63-76.

Meynard, J.-M. (2010) "Avant-propos". In Muchnik, J. and C. de Sainte Marie (eds.), Le temps des Syal, Paris: Editions Quæ, pp. 7-11.

Molle, F. (2008) "Nirvana concepts, narratives and policy models: Insights from the water sector." Water Alternatives, Vol. 1, pp. 131-156. 
Morin, E. (1977). La méthode. 1 : La Nature de la Nature. Paris: Editions du Seuil, collection Points. Norman, D.W. (1980) The Farming Systems Approach: Relevance for the Small Farmer. East Lansing: MSU Rural Development Paper No. 5. Department of Agricultural Economics, Michigan State University.

Osty, P.-L. (1978) "L'exploitation agricole vue comme un système. Diffusion de l'innovation et contribution au développement." Technical Information Bulletin of the Ministry of Agriculture Vol., pp. 43-49.

Pélissier, P. (1966). Les paysans du Sénégal : les civilisations agraires du Cayor à la Casamance. SaintYrieix: Imprimerie Fabrègue.

Pélissier, P. (1979) "Le paysan et le technicien : quelques aspects d'un difficile face-à-face". Actes du colloque de Ouagadougou 4-8 décembre 1978, " Maîtrise de l'espace agraire et développement en Afrique tropicale. Logique paysanne et rationalité technique »: ORSTOM, Centre National de la Recherche Scientifique et Technologique de la Haute-Volta, pp. 1-8.

Pélissier, P. and G. Sautter. (1970) "Bilan et perspectives d'une recherche sur les terroirs africains et malgaches (1962-1969)." Etudes rurales, Vol. n³7-38-39, pp. 7-45.

Piaget, J. (1968). Le Structuralisme. Paris: coll. Que sais-je ?, P.U.F.

Pillot, D. (1987) Recherche développement et farming system research. Concepts, approches et méthodes. Paris: Réseau Recherche-Développement. pp. 40.

Reboul, C. (1976) "Mode de production et systèmes de culture et d'élevage." Economie rurale, Vol. 112 , pp. 55-65.

Ribot, J.C. (1999) "Decentralisation, Participation and Accountability in Sahelian Forestry: Legal Instruments of Political-administrative Control." Africa, Vol. 69, pp. 23-64.

Sautter, G. and P. Pélissier. (1964) "Pour un atlas des terroirs africains. Structure type d'une étude de terroir." L'Homme, Vol. IV, pp. 56-72.

Sebillotte, M. (1982) "Les systèmes de culture. Réflexions sur l'intérêt de cette notion à partir de l'expérience acquise en région de grande culture". Séminaire du département d'Agronomie INRA, 1618 mars, Paris, pp. 63-80.

Sébillotte, M. (1974) "Agronomie et agriculture. Essai d'analyse des tâches de l'agronome." Cahiers de l'ORSTOM, Vol. 24, pp. 3-25.

Tourte, R. (1978) Pour une étude régionalisée des systèmes techniques de production agricole en Côte d'Ivoire. Montpellier, France: IRAT-GERDAT.

Tourte, R. and R. Billaz. (1982) "Approche des systèmes agraires et fonction recherchedéveloppement. Contribution à la mise au point d'une démarche." L'Agronomie tropicale, Vol. 37, pp. 223-231.

Tripp, R. (1985) "Anthropology and on-farm research." Human organization, Vol. 44, pp. 114-124. Turner, B.L., II and S.B. Brush (1987). Comparative Farming Systems. New York: The Guilford Press. Venot, J.-P. and J. Krishnan. (2011) "Discursive framing: Debates over small reservoirs in the rural South." Water Alternatives, Vol. 4, pp. 316-324.

Vissac, B. (1979) Éléments pour une problématique de recherche sur les systèmes agraires et le développement. Toulouse, France: INRA-SAD.

von Bertalanffy, L. (1968). General System theory: Foundations, Development, Applications, : . New York: George Braziller.

Zadeh, L.A. (1962) "From circuit theory to system theory." Proceedings of the IRE, Vol. 50, pp. 856865. 